\title{
Continuity and Change in the Presidential Money Primary
}

\author{
Randall E. Adkins and Andrew J. Dowdle
}

From 1980 to 2000 the candidate that raised the most campaign funds before the start of the primary season tended to win the party nomination. Adkins and Dowdle (2002) found that the positive effect of candidate performance (as measured by national poll results, change in candidate viability, and length of candidacy) and campaign organization (as measured by the amount of money the candidate's campaign spent on fundraising, size of the candidate's electoral constituency, and whether the candidate self-financed his campaign) explained much of the variation in fundraising in the months before the Iowa caucuses that make up the money primary. In this research two OLS regression models were generated to examine whether developments such as frontloading and campaign finance reforms, which occurred prior to the 2004 nomination cycle, demonstrated change or continuity in presidential money primary. Overall, the results suggest a great degree of similarity, even though candidates may now be running harder to raise more money in a shorter period of time.

Campaigning for president became candidate-centered even before the adoption of reforms in the presidential nomination process during the 1970s (e.g., Reiter 1985). In the spring of 1960, for example, Massachusetts Senator John Kennedy sought to prove to political elites within the Democratic Party that his Catholicism would not be an issue with voters in November. To do so, he sought primary victories in heavily protestant states like West Virginia, and it is common knowledge that he spent heavily there in order to win. In spite of the campaign finance reforms of the 1970s that were intended to level the financial playing field in the presidential nomination process, the accumulation of resources by the candidate and his or her campaign remained a critical factor in the success of winning the Democratic or Republican Party's presidential nominations. While raising money is not the most important factor in understanding why candidates win their party's nomination, it is imperative that candidates raise money in order to continue the campaign (Norrander 2000, 2006; Adkins and Dowdle 2000). As Jesse Unruh, the former Speaker of the California State Assembly, said in an interview for Look magazine in 1962, "Money is the mother's milk of politics." Without a fresh supply of cash the campaign cannot remain alive and certainly cannot thrive.

The authors would like to thank Wayne Steger for his helpful comments. This article was accepted pending revision prior to the recent change in editorial staff.

RANDALL E. ADKINS is an associate professor of political science at the University of NebraskaOmaha. ANDREW J. DOWDLE is an assistant professor of political science at the University of Arkansas.

The American Review of Politics, Vol. 28, Winter, 2007-2008: 319-341

(C)2007 The American Review of Politics 
Prior to the start of the caucus and primary season in January of the presidential election year, candidates compete with each other in the form of a "money primary" to raise funds from partisan donors. Campaign funds are raised from different sources including individual contributors, political action committees, loans to the campaign by outside sources or by the candidate, and federal matching funds. Unlike congressional elections, only a small portion of a presidential campaign's warchest comes from political action committees and, by far, most of each campaign's funds come from individual donors (Brown, Powell, and Wilcox, 1995). Further, most aspirants for the nomination raise a sizeable chunk, if not a majority, of their campaign funds before the caucus and primary season even begins (Hinckley and Green 1996; Damore 1997). This is, of course, true for all candidates except the party's nominee who will continue to raise funds long after the other candidates are winnowed from the contest, but the point is that everyone must raise money early to be competitive.

The reforms of the 1970s forced candidates and their campaigns to adopt new strategies to win the presidential nomination and the new money primary played an important role in those changes. First, the McGovernFraser reforms in the Democratic Party (and similar reforms in the Republican Party) expanded the number of people that candidates needed to communicate with if they wanted to win their party's nomination from party elites to caucus and primary voters (Aldrich 1980a, 1980b). Second, the Federal Election Campaign Act of 1971 (and the amendments to it in 1974 and 1976) altered how nomination aspirants raised the money necessary to communicate with this new target audience (Brown, Powell and Wilcox 1995). These events dramatically changed the presidential nomination process by significantly increasing the need for campaign funds and made raising those funds significantly more difficult.

The importance of early fundraising was very apparent by the early 1980s. Damore (1997) reports that 42 percent of funds were raised in the 1984, 1988, and 1992 Democratic nomination contests before the caucuses or primaries were held. Republican aspirants for the presidential nomination embraced the idea of raising early funds even more enthusiastically. Hinckley and Green (1996) found that in 1988 candidates for the Republican Party nomination collected between 67 percent and 87 percent of their total funds during the pre-primary period.

In the late 1990s it became clear that raising a large sum of early money would not only establish candidate viability in the eyes of voters and the press, but it would also discourage potential rivals. In 2000, a number of potentially strong Republican competitors tossed their proverbial hat in the ring only to drop out after George W. Bush raised $\$ 37$ million by mid-1999, which propelled him into a commanding lead in the money primary (Balz 1999). 
The outcome of the money primary is important for understanding which candidate wins each party's presidential nomination for many reasons. Dowdle, Adkins, and Steger (2008) discovered that early fundraising is not the best explanation of performance in polls taken before the primary season begins even though the two are highly correlated. Paolino (1994) found that fundraising plays an important role in influencing news media coverage of presidential campaigns. On the other hand, Cohen, Karol, Noel, and Zaller (2008) questioned the independent effect of fundraising in presidential nominations, but there is still good reason to believe that money plays an important role in the campaign. For example, in their analysis of the 2000 Republican presidential nomination contest, Adkins and Dowdle (2004) established that even though John McCain was able to win very important early primaries in New Hampshire and Michigan, he was unable to capitalize on those victories because his campaign lacked the resources to construct field operations in the states that followed. Additionally, Norrander (2006) confirmed that fundraising success plays an important role in the decision about whether to continue campaigning or withdraw from the race.

If early fundraising is important to winning the nomination, then it is important to understand the dynamics of raising funds. Brown, Powell and Wilcox (1995) examined the relationship between fundraising methods such as fundraising networks and the patterns of campaign contributors. Hinkley and Green (1996) tested campaign-driven and organizational-driven models of fundraising and found greater support for the organizational-driven variables such as money spent on fundraising. Adkins and Dowdle (2002) found that factors affecting both candidate performance (such as national poll results and voter evaluations of candidate viability), along with measures of campaign organization (such as how much the campaign spent on fundraising and the candidate's home electoral constituency) were responsible for explaining variation in fundraising by candidates for the presidential nominations during the pre-primary season. Goff (2004) contrasts the emergence of presidential candidates as they compete for campaign funds in the 1988 and 2000 presidential nomination races when the incumbent president did not seek the nomination of either party. The findings of this study suggest that establishing fundraising success is the best way to establish candidate viability.

In recent years two major changes to the presidential nomination process may have altered the dynamics of the money primary. First, it is logical to assume that early fundraising is even more important given the "frontloading" of presidential caucuses and primaries to a point in time even earlier into the nomination process (Mayer and Busch 2004). Table 1 shows that the number of states holding primaries before March 15 rose from 15 percent in 1976 to 76 percent in 2008 and the number of states holding 
Table 1. States Holding Primaries Before February 15 and March 15, 1976-2008

\begin{tabular}{lccccccccc}
\hline & 1976 & 1980 & 1984 & 1988 & 1992 & 1996 & 2000 & 2004 & 2008 \\
\hline $\begin{array}{l}\text { Total Number } \\
\text { of Primaries }\end{array}$ & 27 & 36 & 30 & 37 & 39 & 42 & 43 & 39 & 38 \\
$\begin{array}{l}\text { Number Before } \\
\text { February 15 }\end{array}$ & 0 & 0 & 0 & 0 & 0 & 0 & 2 & 11 & 22 \\
$\begin{array}{l}\text { Percent Before } \\
\text { February 15 }\end{array}$ & $0 \%$ & $0 \%$ & $0 \%$ & $0 \%$ & $0 \%$ & $0 \%$ & $5 \%$ & $28 \%$ & $58 \%$ \\
$\begin{array}{l}\text { Total Number } \\
\text { of Primaries }\end{array}$ & 27 & 36 & 30 & 37 & 39 & 42 & 43 & 39 & 38 \\
$\begin{array}{l}\text { Number Before } \\
\text { March 15 }\end{array}$ & 4 & 8 & 7 & 21 & 14 & 22 & 26 & 26 & 29 \\
$\begin{array}{l}\text { Percent Before } \\
\text { March 15 }\end{array}$ & $15 \%$ & $22 \%$ & $23 \%$ & $57 \%$ & $36 \%$ & $52 \%$ & $60 \%$ & $67 \%$ & $76 \%$ \\
$\begin{array}{l}\text { Sources: Presidential Elections, 1789-1996. Washington: Congressional Quarterly, 1997. Vital Sta- } \\
\text { tistics on American Politics, 2001-2002. Washington: Congressional Quarterly, 2002. Vital Statistics } \\
\text { on American Politics, 2005-2006. Washington: Congressional Quarterly, 2006. Rhodes Cook, Race } \\
\text { for the Presidency: Winning the 2008 Nomination. Washington: Congressional Quarterly, 2008. }\end{array}$ \\
\hline
\end{tabular}

primaries before February 15 increased from none in 1996 to 58 percent in 2008. When campaigns must compete so soon in such a large number of caucuses and primaries, they need to raise the funds to do so before the nomination season even begins. Table 2 shows that by 2000 both Democrats and Republicans were cumulatively raising over 80 percent of their campaign funds before the start of the year prior to the presidential election. The need for additional campaign funds has led to the adaptation of new technology, such as the internet, to fundraising, and the perfection of older methods such as the pursuit of super-donor/fundraisers (e.g., the "Pioneers" who each raised $\$ 100,000$ or more for George W. Bush in 2000).

Second, the Bipartisan Campaign Reform Act of 2002 (BCRA) raised the contribution limits that individuals could donate from $\$ 1,000$ to $\$ 2,000$ (and then indexed the contribution limits to inflation). ${ }^{1}$ This legislation appears to be affecting the calculus of accepting federal funds that match up to the first $\$ 250$ of a contribution. Candidates that accept matching funds must also agree to abide by an overall spending limit and spending limits within each state. For example, in 2004 the effective primary expenditure limit was $\$ 44,772,000$ once adjustments were made for changes in the cost of living allowance and fundraising expenses (which do not count against 
Table 2. Percentage of Total Funds Raised by Candidate in Year Prior to Election

\begin{tabular}{|c|c|c|c|c|c|}
\hline $\begin{array}{l}\text { Election } \\
\text { Cycle }\end{array}$ & $\begin{array}{l}\text { Political } \\
\text { Party }\end{array}$ & $\begin{array}{c}\text { First } \\
\text { Quarter }\end{array}$ & $\begin{array}{l}\text { Second } \\
\text { Quarter }\end{array}$ & $\begin{array}{c}\text { Third } \\
\text { Quarter }\end{array}$ & $\begin{array}{l}\text { Fourth } \\
\text { Quarter }\end{array}$ \\
\hline 2004 & Democrats & 10 & 16 & 22 & 36 \\
\hline 2000 & Republicans & 8 & 36 & 62 & 87 \\
\hline 2000 & Democrats & 19 & 42 & 65 & 83 \\
\hline 1996 & Republicans & 16 & 35 & 51 & 76 \\
\hline 1992 & Democrats & Less than 1 & 4 & 13 & 60 \\
\hline 1988 & Republicans & 3 & 18 & 41 & 65 \\
\hline 1988 & Democrats & 7 & 31 & 48 & 71 \\
\hline 1984 & Democrats & 14 & 31 & 45 & 69 \\
\hline 1980 & Republicans & 9 & 20 & 35 & 70 \\
\hline \multicolumn{6}{|c|}{$\begin{array}{l}\text { Note: Figures represent cumulative percentage of all money raised across a given nomination cycle } \\
\text { First quarter figures represent money raised during first quarter of year prior to election (e.g., Janu- } \\
\text { ary-March } 2003 \text { for } 2004 \text { Democratic nomination) as percent of total money raised during entire } \\
\text { campaign, Second quarter figures represent money raised during first quarter of year prior to election } \\
\text { (e.g., April-June } 2003 \text { for } 2004 \text { Democratic nomination) as percent of total money raised during } \\
\text { entire campaign, First quarter figures represent money raised during first quarter of year prior to } \\
\text { election (e.g., July-September } 2003 \text { for } 2004 \text { Democratic nomination) as percent of total money } \\
\text { raised during entire campaign, Fourth quarter figures represent money raised during last quarter of } \\
\text { year prior to election (e.g., October-December } 2003 \text { for } 2004 \text { Democratic nomination) as percent of } \\
\text { total money raised during entire campaign. Sources: Individual Reports of Receipts and Disburse- } \\
\text { ments for Candidates for Presidential Nomination, } 1979-2004 \text {, Federal Election Commission. }\end{array}$} \\
\hline
\end{tabular}

fundraising limits). ${ }^{2}$ Before the 2000 presidential election cycle only two candidates decided to forego the federal matching fund provisions because they anticipated raising more money than the matching fund spending caps would permit. Once the contribution limits were raised, however, both oward Dean and John Kerry decided to sacrifice federal matching funds in the 2004 Democratic nomination cycle in order to compete against each other and against President Bush who did not accept matching funds either.

The question addressed in this research then is whether the factors that explain the outcome of the money primary are the same or different since these changes were implemented. In order to understand this question, the 2004 nomination cycle will be compared to the model of the 1980-2000 nomination cycles identified by Adkins and Dowdle (2002).

\section{Factors Affecting the Money Primary}

In order to discern whether the factors that explain the outcome of the money primary are effectively the same or different after implementation of changes in the primary calendar and changes to campaign finance law, the 
results of the model offered by Adkins and Dowdle (2002) were compared to the results of a similar model of the 2004 money primary. The dependent variable in this study represents the total revenue raised by each presidential candidate's principal campaign committee as of the date that the Federal Election Commission (FEC) took delivery of the campaign's official Statement of Organization. ${ }^{3}$ After that presidential candidates are required to file reports with the FEC of their receipts and disbursements every quarter in the year prior to the election and every month in the year of the election. Since the 1980s the date of the first delegate selection event, the Iowa caucuses, has varied from the first week of January to mid-February. As a result, December 31 of the year prior to the election was used as the operational end of the money primary process because it also serves as the end date for information to be included by candidate campaigns in the January Monthly Report filed with the FEC. ${ }^{4}$ In order to control for the effects of inflation and the context of individual election cycles, the total revenue received is calculated as a percentage of the funds that each candidate raised, relative to the winner of the money primary. ${ }^{5}$ For example, in the 2000 Republican primary season George W. Bush, who raised the most money by the end of the money primary $(\$ 70,669,706)$, scored 100 percent, and John McCain, who came in second $(\$ 21,375,031)$, scored 30 percent.

Adkins and Dowdle (2002) utilized an OLS regression model that identified six independent variables to explain fundraising during the money primary. Following the example set by Hinckley and Green (1996), the independent variables were artificially divided into two categories: (1) candidate performance and (2) organizational elements of the candidate's campaign. The measures of candidate performance include initial national poll results, changes in perceptions of candidate viability before the primaries begin, and length of time as a candidate. The organizational elements of the campaign are measured by the candidate's electoral constituency size, the amount of money spent by the campaign on fundraising, and whether candidates choose to forego federal matching funds. In all but one case, the measures utilized here replicate those used by Adkins and Dowdle (2002).

\section{National Poll Results}

A number of reputable polling organizations measure voter preferences during the pre-primary period of the presidential nomination process. The results of these polls can attract the attention of the news media and even fuel the public's interest in a candidate. The link between national preference polls and eventual nomination victory is confirmed in many studies of presidential nomination politics (Mutz 1995; Mayer 1996; Hinckley and Green 1996; Adkins and Dowdle 2000, 2001a, 2001b; Norrander 2000; and 
Steger 2000). Adkins and Dowdle (2002) examined the link between national preference polls and fundraising and found a significant, positive relationship. In her study of the impact of initial resources on the winnowing of the field of candidates, Norrander (2000) analyzed the effect of fundraising along with other factors specific to candidates including poll ratings. She found that fundraising is correlated with how a candidate performs in the early national polls, which suggests that wealthier campaigns "cannot buy popular support in the primaries if that candidate does not already have a significant level of support in the national polls prior to the election year" (p. 5). In the past some candidates like John Connally and Phil Gramm were able to raise substantial funds, but spent those resources without attaining even a moderate level of public support.

In this study national poll results is measured as each candidate's average level of support among self-identified partisans in the national Gallup polls that asked partisan voters about their choice for their party's nominee that was taken during the third quarter of the year prior to the election (e.g., July, August, and September of 1999 for the 2000 campaign). ${ }^{6}$ These data mirror what the Gallup organization refers to as one-year-out polls and represent each candidate's general level of public support a year prior to the general election. Newport (1999) concluded that the Gallup organizations polls are a relatively good representation of the eventual winner. The poll results were averaged and then calculated as a percentage of the result that each candidate scored, relative to the candidate with the highest score in order to control for (1) changes in the responses of Gallup's survey ${ }^{7}$ and (2) the context of individual election cycles. For example, George W. Bush achieved an average rating in the Gallup polls of 62 percent in the third quarter of 2000 and scored 100 percent; but John McCain averaged 5 percent across the same polls and scored 8 percent relative to Bush.

\section{Change in Viability}

Many studies utilize a number of different measures and methods to examine the effect of changes in voter perception of candidates on (1) individual caucuses and primaries or (2) the final primary vote total. Aldrich (1980a, 1980b) and Bartels $(1985,1988)$ both found evidence supporting the effect of campaign momentum on future campaign success. Momentum is generally a short-term trend that comes from better than expected efforts in early caucuses or primaries. Most recent models of the presidential nomination process offer a measure of campaign momentum including success in initial primaries (Adkins and Dowdle 2000, 2001a, 2001b; Norrander 2000), past performance in previous primaries (Grush 1980; Norrander 1993; Mutz 1995; Hinckley and Green 1996; Damore 1997; Haynes, Gurian, and 
Nichols 1997), or media coverage (Gurian 1986, 1990, 1993a, 1993b, 1996; Gurian and Haynes 1993).

While momentum is short-lived and may disappear as quickly as it appeared, another measure - candidate viability - represents voter perceptions of a candidate's chance of winning the presidential nomination. Sources of candidate viability include, among other things, name recognition, personal characteristics, political experience, and positions on issues. Campaign events, media coverage, and campaign success play an important role in developing viability, but candidates can remain viable in the absence of campaign momentum. Guerrant and Gurian (1996) found that viability played an important role in voter preferences of potential nominees, but was more likely to do so in later stages of the campaign because voters needed more time to absorb information about the candidates. Thus, it may take more time for voters to perceive a candidate as viable, but that should have a greater effect on voter preferences between potential nominees. Earlier research on candidate viability used measures of convention delegates (Gurian and Haynes 1993; Guerrant and Gurian 1996; Damore 1997; Haynes, Gurian, and Nichols 1997), relative to the number of delegates won by other candidates or the delegates still available at a specific point in time during the primary season.

Given that the money primary ends as the caucus and primary season begins, measures of momentum or changes in viability based on either (1) primary and caucus victories or (2) delegates accumulated are not useful. The effect of the change in candidate viability on the money primary must be measured from a point in time after which all candidates have officially entered in the race until the beginning of the caucus and primary season. Dowdle, Adkins, and Steger (2008) discovered that the best predictor of candidate viability before the first caucuses and primaries are held is mass partisan support measured in national preference polls. Further, they found that this support is remarkably stable throughout the year before the election, but that campaign-related factors such as campaign disbursements, elite endorsements, and news coverage also make significant contributions to understanding candidate viability.

Generally, presidential candidates formally enter the race by the third quarter of the year prior to the presidential election. Polling organizations conduct preference polls before the primary season starts and continue until the eventual winner is known. Thus, a measure of the change in candidate viability before the primaries can be attained by computing the change in voter preferences through national polls. In this study, the change in candidate viability represents the difference in the level of support a candidate finds among self-identified partisans that is taken in the last poll of the Gallup organization before the Iowa caucuses and the average of all national 
Gallup polls taken during the third quarter of the year prior to the election. Similar to other variables, the scores for each candidate were calculated as a percentage of the result that each candidate scored, relative to the candidate with the highest score. Thus, the change in viability represents the candidate's increase or decrease in support in the closing months before the primaries begin. In their earlier study of the money primary, Adkins and Dowdle (2002) found a positive and significant relationship between a change in candidate viability and fundraising success.

\section{Length of Candidacy}

Before the reforms of the 1970s, the conventional wisdom was that an early declaration of candidacy was a sign of weakness. Weaker candidates entered the race early because they needed longer to build support among party elites and voters. This changed for a number of reasons in the 1970s. The nomination of George McGovern in 1972 and Jimmy Carter in 1976 proved that early entrance was important for overcoming limited name recognition if the candidate could put together a strong retail strategy in the Iowa caucuses and New Hampshire primary. Additionally, early entry was important for candidates planning to accept federal matching funds because, in order to qualify for them, the campaign had to be officially recognized by the FEC. Finally, early entrance became the norm by the 1980s and candidates who could not raise enough money or build a strong campaign organization dropped out of contention. In fact, in 1996 and 2000 many of the candidates in the Republican Party formally organized their campaigns early, but withdrew before the primary season started because they feared they would be unable to raise the money necessary to run a successful campaign. ${ }^{8}$

The length of time a candidate is in the campaign is measured by the number of days from the date the FEC receives documentation of the candidate's Statement of Organization until January 1 of the election year. While this date rarely reflects the date of the formal announcement speech, it is the best measure of formal entrance into the competition for financial resources. Other dates such as the announcement of the formation of authorized committees were considered, but the date that the FEC receives the Statement of Organization from the principal campaign committee is recognized by the FEC for the purpose of enforcing campaign finance regulations and providing matching funds for qualified contributions. If everything were equal one might expect that candidates in the campaign longer would be able to raise more campaign contributions, but Damore (1997) found most long-shot candidates never raise much in campaign funds primarily due to lack of the perception of viability among campaign contributors. Entry date, therefore, represents a control variable that is not expected to have a significant 
relationship to fundraising. Adkins and Dowdle (2002) found no statistically significant relationship between length of candidacy and fundraising success.

\section{Electoral Constituency Size}

Candidates from larger states should be able to raise more funds than their counterparts from smaller electoral constituencies. In their research on the Democratic and Republican nomination campaigns in 1988, Hinckley and Green concluded that campaigns tend to rely on the candidate's "own existing political base" for raising money (1996, 704). In support of this, Brown, Powell, and Wilcox (1995) wrote, "The first candidate resource analyzed is the ability to create or activate the financial networks within that candidate's home state. Sitting governors and some senators have this resource readily available to them; many representatives to a lesser extent do also. The larger the state and the more politically powerful the candidate, the more important this resource is" (p. 12). For example, if all else were equal the governor of California would find it easier to raise the needed resources to compete for the party nomination than the governor of Arkansas. Adkins and Dowdle (2002) found no statistically significant relationship between electoral constituency size and fundraising success. In spite of that, the variable is included here in order to make valid comparisons between the models discussed.

This variable is measured as the size of the electoral constituency the candidate represents (in millions) reported in the national census data taken prior to that election. The largest electoral constituency (state or congressional district) represented prior to or after holding that office was used for sitting or former vice presidents and cabinet members. Members of the House of Representatives were assigned the population of their home congressional district. Candidates that have not held elective office were scored zero. As with other variables, the electoral constituency size of each candidate was calculated as a percentage of the population of the candidate's electoral constituency, relative to the population of the largest electoral constituency of all candidates within the race for the party nomination. For example, in 2000, George W. Bush of Texas (the largest constituency of any candidate in the race) scored 100 percent; and John McCain of Arizona, which had a population of $5,130,000$, scored 25 percent.

\section{Fundraising Expenditures}

To be competitive presidential candidates must raise financial resources and increasingly, candidates start campaigning early in order to raise those 
resources. In order to raise money, campaigns must devote financial and human resources to the fundraising element of the campaign. Hinckley and Green (1996) contend that although spending money to raise money through direct mail or special events does not measure the activities of the candidate, it does represent an important organizational function of the campaign. Similarly, Mutz concluded of presidential candidates that, "Their ability to make mass fund-raising appeals through direct mail or broadcast advertising may, in turn, be constrained by the size of their campaign war chests (1995, 1027)." Adkins and Dowdle (2002) found a positive and significant relationship between spending campaign funds on fundraising and overall fundraising success.

The data on candidate expenditures of fundraising was collected from Reports of Receipts and Disbursements filed with the FEC. ${ }^{10}$ This variable represents the percentage of campaign funds spent on fundraising, relative to the candidate who spent the most on fundraising in that party's nomination cycle, which controls for inflation and differences in election cycles. In the 2000 Democratic race, Al Gore, who spent $\$ 5,905,099$ on pre-nomination fundraising, scored 100 percent; and Bill Bradley, who committed $\$ 4,825,927$, scored 82 percent.

\section{Federal Financing}

In their earlier study of the money primary, Adkins and Dowdle (2002) utilized a dummy variable to take into consideration the candidacies of Steve Forbes in 1996 and 2000, which were primarily self-financed through personal loans to his campaigns. John Connally in 1980 and George W. Bush in 2000 were not included because although they, "chose not to accept federal matching funds that would have subsequently required them to conform to state spending limits and could have influenced their performance in the upcoming primaries and caucuses, they were still required to abide by limitations on individual and group contributions as provided by the Federal Election Campaign Act, which certainly affected their fundraising ability (Adkins and Dowdle 2002, 268)." Adkins and Dowdle (2002) found the selffinancing variable to have a significant influence on fundraising ability.

In this study the variable is theoretically and methodologically different for two reasons. First, self-financing by the candidate through contributions or loans to the campaign is rare. Second, the trend since the 2000 election cycle suggests that the conformity previously seen among candidates to accept the spending limits that accompany the acceptance of federal matching funds has disappeared. A few candidates in each campaign cycle will chose not to accept the matching provision because they can now raise more 
money than spending limits mandated by the matching fund provision permits. In 2004, for example, Dean and Kerry both rejected these funds. Candidates opting out of the federal matching fund pool were coded "1."

In summary, the modified money primary model is represented by the equation:

$$
\mathrm{CMR}=\mathrm{a}+\mathrm{b} 1 \mathrm{GP}+\mathrm{b} 2 \mathrm{CV}+\mathrm{b} 3 \mathrm{LC}+\mathrm{b} 4 \mathrm{EC}+\mathrm{b} 5 \mathrm{MF}+\mathrm{b} 6 \mathrm{FE}+\mathrm{e}
$$

where

$\mathrm{CMR}=$ cumulative money raised,

$\mathrm{GP}=$ third quarter Gallup poll results,

$\mathrm{CV}=$ change in viability from third quarter Gallup polls to end of money primary,

$\mathrm{LC}=$ length of candidacy (in days),

$\mathrm{EC}=$ size of the candidate's electoral constituency,

$\mathrm{MF}=$ whether the candidate opted out of the federal matching fund system, and

$\mathrm{FE}=$ fundraising expenditures by the campaign.

Two OLS regression models were generated in order to ascertain whether changes have occurred in presidential nomination fundraising patterns. Nomination contests with incumbents were not included in the models since such races are inherently different. In fact, in no election during the time period under study did an incumbent president lose a bid for re-nomination. Therefore, this excludes the 1984, 1992, and 2004 Republican primaries and the 1980 and 1996 Democratic primaries. Even though it is the first presidential election after the passage of the Federal Election Campaign Act, the 1976 election cycle was excluded because some aspects of the 1974 and 1976 amendments were not yet in effect. For example, the FEC did not require candidates to report summary statistics on fundraising expenditures until 1980.

The first OLS regression model herein replicated Adkins and Dowdle's (2002) study of fundraising in contested presidential nomination campaigns from 1980-2000 (with the exception of the change to the self-financing variable to a measure representing whether candidates were opting out of the federal matching fund system). The sample for this model includes fortynine cases representing the contenders for the Democratic and Republican nominations. ${ }^{11}$ The second model represents the 2004 Democratic nomination contest with the sample for this model including nine cases. ${ }^{12}$ The results of each model are presented in Table $3 .{ }^{13}$ 
Table 3. Predicted Share of Fundraising During the Money Primary, 1980-2000 and 2004

\begin{tabular}{lcc}
\hline & $1980-2000$ & 2004 \\
\hline Gallup Poll Results & $.44^{* *}$ & $.27 *$ \\
& $(4.71)$ & $(2.07)$ \\
Length of Candidacy & .01 & -.01 \\
& $(.21)$ & $(-.22)$ \\
Change in Viability & $.69 * *$ & .28 \\
& $(4.31)$ & $(1.26)$ \\
Fundraising Expenditures & $.42^{* *}$ & $.59 * *$ \\
& $(4.92)$ & $(4.24)$ \\
Opt Out of Matching Funds & $44.20^{* *}$ & $11.13 * *$ \\
& $(3.21)$ & $(2.80)$ \\
Electoral Constituency Size & 13.76 & -.20 \\
& $(1.45)$ & $.-.86)$ \\
Intercept & 7.42 & $(.32)$ \\
& $(.97)$ & 9 \\
N & 49 & .84 \\
Adjusted $\mathrm{R}^{2}$ & .71 & 5.81 \\
Standard Error & 18.16 & \\
NOTE: Coefficients are unstandardized ordinary least squares (OLS) regression values; t scores are \\
in parentheses.
\end{tabular}

\section{Results}

Overall, the models suggest a high degree of continuity in the factors that affect campaign fundraising at the presidential level and those that do not. First, the findings of Adkins and Dowdle (2002) suggest that from 1980 to 2000 the significant factors affecting the money primary were the results of national polls, changes in perceptions of candidate viability, fundraising expenditures, and whether a candidate opted out of the federal matching funds system. ${ }^{14}$ As expected, the length of candidacy did not play a role in fundraising success, but surprisingly the size of the candidate's electoral constituency did not either.

The results of the model for the 2004 nomination contest yielded very similar results to the model for 1980-2000. Both national poll standings and fundraising expenditures were still statistically significant predictors of 
fundraising success. Further, the length of candidacy and the size of the candidate's electoral constituency were not.

One factor that demonstrated a different outcome in the model for the 2004 nomination cycle was the change in viability of candidates. Adkins and Dowdle (2002) reported that overall this variable had a positive and significant effect. By running separate models for Democrats and Republicans, they also discovered that the outcome was true for Democrats but not Republicans. Based on those findings, it is reasonable to assume that this variable would yield a positive and significant result for the 2004 Democratic nomination contest, but it did not. It is reasonable to conclude that either the number of cases was insufficient to determine statistical significance or changes in viability were not as important in the 2004 race as they had been in previous Democratic contests. The latter seems unlikely because the winner of the money primary in 2004, Howard Dean, surged in the polls at the end of 2003. Alternatively, the late entrance of Wesley Clark to the race may have skewed the variable values for this particular cycle. It seems most likely, however, that the variable lacked statistical significance because the model yielded six independent variables with only nine cases.

The last variable included in the model was the decision to accept or reject federal financing. This variable was altered somewhat from the original study by Adkins and Dowdle (2002) where it was a dummy variable representing the single self-financed candidate, Steve Forbes. This variable was both positive and significant in both the 1980-2000 and 2004 models, which means that candidates opting out of the federal matching fund system were more likely to find success in the money primary and beyond. Two candidates did so in 2004, former Vermont Governor Howard Dean and Senator John Kerry. ${ }^{15}$ Table 2 reveals that over the last three decades increasingly larger percentages of total campaign funds were raised during the money primary. That number grew from between 60 percent to 70 percent in the 1980s to over 80 percent in both parties during the 1999 calendar year in preparation for the 2000 presidential election. Interestingly, only 36 percent of the $\$ 350$ million dollars contributed in the 2004 election cycle was collected before January 1, 2004, which was the lowest for the time span under study. In 2004, the eventual nominee, John Kerry, collected over half the contributions to Democratic contenders, but had raised less than 18 percent of that total by the end of 2003.

This does not mean that the top Democratic hopefuls had difficulty raising early money. By the end of 2003, Howard Dean had raised $\$ 41$ million and John Kerry had raised $\$ 23.5$ million. By comparison, Al Gore raised nearly \$29 million in 1999 and Bill Bradley raised just under less than $\$ 23$ million. The lower percentage represents two important differences relative to the 2004 Democratic campaign. First, unlike 2000 Kerry did not 
emerge as the party's frontrunner until after his victories in Iowa and New Hampshire. ${ }^{16}$

When that occurred, fundraising success followed and Kerry surpassed Dean in February of 2004. His campaign went on to raise more than $\$ 200$ million before the Democratic National Convention in August of 2004. In contrast, Gore raised only \$24 million in 2000 for his nomination campaign. Kerry's late financial rush was exacerbated by a second factor. Since he was not bound by the spending limits placed on candidates that accept the federal matching funds, he was in a position to surpass previous Democratic fundraising and spending records. In contrast, Gore had little incentive to raise additional money during the later stage of the nomination season because he was close to reaching the federal spending limit.

The predicted and actual ordinal rankings of candidates in the money primary from 1980-2004 are presented in Table 4. In the first model of the money primary, Adkins and Dowdle (2002) predict most of the winners and runner-ups from 1980-2000 with only a few exceptions (most notably Gary Hart who withdrew and reentered the race in 1988). The 2004 model correctly predicted that Howard Dean would win the money primary, but reversed the order of Wesley Clark and Richard Gephardt who finished second and third, respectively.

\section{Implications for 2008}

The findings of this study suggest that despite changes to the fundraising environment there is surprising similarity in the factors that help or hinder fundraising by individual campaigns. Candidates with high polls numbers and a willingness to spend money on fundraising are still going to be able to be relatively successful in the money primary if they can tap their fundraising networks and/or avoid the spending limitations that accompany the federal matching fund system. In the 2007 money primaries, Democrat Hillary Clinton and Republican Rudy Giuliani each had strong poll numbers, spent large amounts of money on fundraising and tapped into welldeveloped fundraising networks. ${ }^{17}$

Aside from these similarities, three environmental changes should have important implications for the 2008 and future money primaries. These include: (1) the collapse of the voluntary federal matching funds system for presidential nominations, (2) the rise of the internet as a fundraising tool, and (3) the emergence of broader fundraising networks. Each will be discussed in turn.

Regarding the federal matching fund system established in the 1970s, Malbin (2006) demonstrated that it was already under extreme duress during the 2004 Democratic nomination process. From 1976-2000 the only 
Table 4. Predicted and Actual Outcome of the Presidential Money Primary, 1980-2004

\begin{tabular}{|c|c|c|c|c|c|}
\hline Year & Party & Showing & $\begin{array}{l}\text { Model } \\
\text { Prediction }\end{array}$ & $\begin{array}{l}\text { Actual } \\
\text { Result }\end{array}$ & $\begin{array}{l}\text { Eventual } \\
\text { Nominee }\end{array}$ \\
\hline 2004 & $\mathrm{D}$ & $\begin{array}{l}\text { Win } \\
\text { Place } \\
\text { Show }\end{array}$ & $\begin{array}{l}\text { Dean } \\
\text { Kerry } \\
\text { Clark }\end{array}$ & $\begin{array}{l}\text { Dean } \\
\text { Kerry } \\
\text { Gephardt }\end{array}$ & Kerry \\
\hline 2000 & $\mathrm{D}$ & $\begin{array}{l}\text { Win } \\
\text { Place }\end{array}$ & $\begin{array}{l}\text { Gore } \\
\text { Bradley }\end{array}$ & $\begin{array}{l}\text { Gore } \\
\text { Bradley }\end{array}$ & Gore \\
\hline 2000 & $\mathrm{R}$ & $\begin{array}{l}\text { Win } \\
\text { Place } \\
\text { Show }\end{array}$ & $\begin{array}{l}\text { Bush } \\
\text { McCain } \\
\text { Forbes }\end{array}$ & $\begin{array}{l}\text { Bush } \\
\text { Forbes } \\
\text { McCain }\end{array}$ & Bush \\
\hline 1996 & $\mathrm{R}$ & $\begin{array}{l}\text { Win } \\
\text { Place } \\
\text { Show }\end{array}$ & $\begin{array}{l}\text { Forbes } \\
\text { Dole } \\
\text { Gramm }\end{array}$ & $\begin{array}{l}\text { Dole } \\
\text { Forbes } \\
\text { Gramm }\end{array}$ & Dole \\
\hline 1992 & $\mathrm{D}$ & $\begin{array}{l}\text { Win } \\
\text { Place } \\
\text { Show }\end{array}$ & $\begin{array}{l}\text { Clinton } \\
\text { Harkin } \\
\text { Tsongas }\end{array}$ & $\begin{array}{l}\text { Clinton } \\
\text { Harkin } \\
\text { Kerrey }\end{array}$ & Clinton \\
\hline 1988 & $\mathrm{D}$ & $\begin{array}{l}\text { Win } \\
\text { Place } \\
\text { Show }\end{array}$ & $\begin{array}{l}\text { Dukakis } \\
\text { Hart } \\
\text { Simon }\end{array}$ & $\begin{array}{l}\text { Dukakis } \\
\text { Simon } \\
\text { Gephardt }\end{array}$ & Dukakis \\
\hline 1988 & $\mathrm{R}$ & $\begin{array}{l}\text { Win } \\
\text { Place } \\
\text { Show }\end{array}$ & $\begin{array}{l}\text { Bush } \\
\text { Dole } \\
\text { Robertson }\end{array}$ & $\begin{array}{l}\text { Robertson } \\
\text { Bush } \\
\text { Dole }\end{array}$ & Bush \\
\hline 1984 & $\mathrm{D}$ & $\begin{array}{l}\text { Win } \\
\text { Place } \\
\text { Show }\end{array}$ & $\begin{array}{l}\text { Mondale } \\
\text { Glenn } \\
\text { Cranston }\end{array}$ & $\begin{array}{l}\text { Mondale } \\
\text { Glenn } \\
\text { Cranston }\end{array}$ & Mondale \\
\hline 1980 & $\mathrm{R}$ & $\begin{array}{l}\text { Win } \\
\text { Place } \\
\text { Show }\end{array}$ & $\begin{array}{l}\text { Reagan } \\
\text { Connally } \\
\text { Bush }\end{array}$ & $\begin{array}{l}\text { Reagan } \\
\text { Connally } \\
\text { Bush }\end{array}$ & Reagan \\
\hline
\end{tabular}

candidates that opted out of the system were John Connally in 1980, Steve Forbes in 1996 and 2000, and George W. Bush in 2000. In 2004 alone, however, three candidates opted out of the system in order to raise more money than the overall spending limits mandated by the matching fund system would allow. This included incumbent George W. Bush, Howard Dean, and John Kerry. As expected, the creation of new "super-donors" that could donate \$2000 under BCRA allowed these candidates to achieve campaign funding levels never before imagined. At first glance, it appears that BCRA did little more than convince frontrunners to opt out of the federal funding 
system. However, it did more than that. In 2008 the only candidates that filed for federal matching funds were Democrats Joe Biden, Chris Dodd, John Edwards, and Dennis Kucinich; and Republicans Duncan Hunter, John McCain, and Tom Tancredo. ${ }^{18}$ Further, Seelye and Bumiller (2008) report that after effectively securing the Republican nomination, John McCain stated that his campaign would not accept matching funds after all because, "we didn't need to." While McCain's quick success in the primaries shows that foregoing matching funds is not a sine qua non for winning either party's presidential nomination, the candidates best-positioned to raise money do not seem to consider them an asset. The acceptance of matching funds was once an automatic choice for almost all candidates, but the increase in the maximum individual contribution (up from $\$ 1,000$ in 2000 to $\$ 2,300$ in 2008) dramatically altered the decision calculus. In addition, the change in the contribution limits also triggered a noticeable change in the larger contributions. One study found that Kerry raised only $\$ 6$ million in contributions of $\$ 200$ or less through March 1, 2004. This accounted for less than twenty percent of his total funds raised. On the other hand, the donors that contributed $\$ 1,000$ or more accounted for more than two-thirds of his total contributions (Campaign Finance Institute, 2005). To put this in perspective, the $\$ 6$ million he raised from smaller donations is equivalent to the amount that he loaned to his campaign just prior to the Iowa caucuses.

A second change that will impact 2008 is the use of the internet to raise money. At one time, momentum from performing well in early caucuses and primaries could be expected to bring new donors or additional donations that would fuel the campaign in subsequent caucuses and primaries. The frontloading of the campaign calendar, however, made this strategy look unfeasible. With campaign costs skyrocketing one would expect that funds must be raised well in advance in order to hire staff, field campaign offices, communicate with potential caucus and primary participants, and perform practically every other necessary activity (including raising additional money). Thus, when candidates run out of campaign funds they should be winnowed out of the nomination process (Norrander 2006). Raising campaign funds over the internet, however, eliminates the lag time typically associated with fundraising and allows the cash of campaign donors to be immediately transferred to other forms of resources. For example, in 2000 John McCain was able to keep his campaign afloat by raising money on-line after his win in the New Hampshire primary (Adkins and Dowdle 2004). In 2004, Howard Dean's campaign placed a priority before the primary season on both mobilizing supporters and raising campaign funds via the internet (Trippi 2004). Although Stromer-Galley and Baker (2006) question whether Dean's was really a grassroots-drive movement, there is no doubt that his ability to raise funds using the internet would be meaningful in future 
campaigns. After winning the Iowa caucuses on January 3, 2008, Barack Obama raised over \$28 million that month. To put this number in the proper perspective, Howard Dean raised only \$27 million during his entire 2004 campaign (Vargas 2008).

The third change that impacts the 2008 money primaries is outreach by campaigns via the internet to non-traditional contributors. In some respects, Pat Robertson's fundraising success in 1988 targeting Christian conservatives represents an early adaptation of this style of fundraising. He raised money from a large number of new donors through smaller direct-mail contributions. The first candidate to see similar success reaching smaller donors on the internet was Howard Dean. In the first three quarters of 2004 Howard Dean's contributions averaged $\$ 77$ per donor compared to \$283 for President Bush (Will 2003). If Malbin's (2006) finding that there was a significant amount of donor turnover for mainstream candidates (such as the 2000 and 2004 Bush campaigns) holds true for non-mainstream candidates, then these facts suggest that there will be very serious alternatives that will emerge to compete with the traditional, elite fundraising networks in 2008. For example, through October 31, 2007, Barack Obama raised \$76 million with most of that money coming online and more than 25 percent of it in contributions of $\$ 200$ or less (Mosk and Solomon 2008). If other presidential hopefuls are able to tap into different potential donor bases via the internet, then influence of the resurgent party elites (see Cohen et al. 2008, and Steger 2008) will be greatly diminished in relation to early polling, news media coverage, and momentum from early caucus and primary victories.

\section{Conclusions}

In spite of the fact that there appears to be continuity in how candidate performance and organization elements of the campaign affect the presidential money primary, there are still factors related to how campaign funds are raised and how much campaigns cost that have changed in recent years. This includes the change in contribution limits included in the BCRA and the rise of frontloading that increases the cost of campaigning. In summary, the money primary appears no more or less stable than it did before these changes were made. Standings in the polls, fundraising networks and resources committed to fundraising still matter. Today, however, it appears that candidates must effectively run faster just to keep pace.

Early money still matters, but it does not determine the outcome of the campaign. While there are benefits to starting the caucus and primary season with money in the bank, candidates that start the caucus and primary season short on cash can be strategic and campaign in the states where they are more likely to win. In 2008, however, changes to the individual contribution 
limits coupled with the internet as a fundraising tool may permit candidates to raise money more quickly during the primary season than the traditional fundraising networks allowed and, therefore, not get washed out in a tidal wave created by the frontrunner.

\section{NOTES}

${ }^{1}$ For a more detailed examination of recent changes in the system of campaign finance and their effects on the presidential nomination process, please see Malbin (2006) and Magelby and Mayer (2008).

${ }^{2}$ http://www.fec.gov/press/bkgnd/fund.shtml (accessed February 1, 2008).

${ }^{3}$ Only funds received by, or transferred to, a candidate's principal campaign committee were included.

${ }^{4} \mathrm{~A}$ summary statistic found on individual Reports of Receipts and Disbursements filed with the Federal Election Commission (FEC form 3P, line 22) shows the total for campaign contributions, federal matching funds, transfers from authorized committees, and loans to the campaign.

${ }^{5}$ As calculated, this variable also represents how well the candidate does in fundraising relative to the overall fundraising environment. Alternatively, Hinckley and Green (1996) used as an independent variable the funds raised by rival candidates. In the research at hand, the authors chose to follow the example of Mayer (1996), Adkins and Dowdle (2000, 2001a, 2001b) and Norrander (2000).

${ }^{6}$ Data reported in The Gallup Weekly Report, The Gallup Report, or The Gallup Poll.

${ }^{7}$ As an example Elizabeth Dole drew an average response of 12 percent in the third quarter of 1999, but formally withdrew from the Republican nomination contest on October 20,1999. Subsequently, she was disregarded from the analysis.

${ }^{8}$ In 1992, Democrat Douglas Wilder withdrew before the Iowa caucuses. In 1996, Republicans Arlen Specter and Pete Wilson pulled out of the contest for the Republican nomination. By 2000, the trend in withdrawal grew to six candidates, including Lamar Alexander, Elizabeth Dole, John Kasich, Dan Quayle, Robert Smith, and Pat Buchanan (who switched to the Reform Party). In 2004, Bob Graham withdrew early and Carol Moseley Braun left just prior to the Iowa caucuses.

${ }^{9}$ Mutz (1995) assumes that money spent on fundraising by each campaign is relatively consistent in relation to the total of funds raised. The correlation between preprimary fundraising expenditures and total pre-primary fundraising, however, was only .66 from 1980-2000.

${ }^{10}$ In fact, the FEC encourages candidates to report fundraising expenditures by exempting such expenses from state spending limits under certain circumstances (See 11 CFR 110.8(c)(2)). This statistic is available in summary form on page 2, form 3P, line 25, column B of the Reports of Receipts and Disbursements for individual candidates by quarter in the years prior to the presidential election and by month in the presidential election year.

${ }^{11}$ Candidates included in the analysis are, for 1980, Anderson, Baker, Bush, Connally, Crane, Dole, and Reagan; for 1984, Askew, Cranston, Glenn, Hart, Hollings, Jackson, McGovern, and Mondale; for 1988 (Democratic Party), Babbitt, Dukakis, Gephardt, 
Gore, Hart, Jackson, and Simon; for 1988 (Republican Party), Bush, Dole, DuPont, Haig, Kemp, and Robertson; for 1992, Brown, Clinton, Harkin, Kerrey, and Tsongas; for 1996, Alexander, Buchanan, Dole, Dornan, Forbes, Gramm, Keyes, and Lugar; for 2000 (Democratic Party), Bradley and Gore; and for 2000 (Republican Party), Bauer, Bush, Forbes, Keyes, and McCain.

${ }^{12}$ Candidates included the analysis for 2004 are Clark, Dean, Edwards, Gephardt, Kerry, Kucinich, Lieberman, Moseley-Braun, and Sharpton. Moseley-Braun dropped out on January 14, 2004, but is included because she remained in the race until the end of the money primary.

${ }^{13}$ In each model, the authors tested for multicollinearity by regressing each independent variable against the remaining independent variables in the model. Since none of the $\mathrm{R} 2 \mathrm{~s}$ of these equations were greater than either .8 or the R2 of the original models, multicollinearity is not a significant problem (Farrar and Glauber 1967; Lewis-Beck 1980). The SPSS diagnostics also suggest no serious problems with multicollinearity.

${ }^{14} \mathrm{As}$ mentioned earlier, the authors replaced the self-financing variable with a variable representing whether candidates accepted or rejected federal matching funds. The result was a decrease in the predicted values for Steve Forbes, but an increase in the predicted values for John Connally and George W. Bush. It was not enough, however, to alter the ordinal finishes during the respective money primaries.

${ }^{15}$ When candidates accept federal matching funds their fundraising expenses within a state are not incorporated into their state-by-state spending totals. Neither candidate was required to report the amount of money spent on fundraising, but both did. As such, the numbers they reported should be met with skepticism as to their validity.

${ }^{16}$ John Kerry's campaign was running behind the others until he injected nearly $\$ 6.4$ million of his own money into his campaign in late December and early January, which was secured through a mortgage of his personal share of the family's home. As the campaign resources of his opponents dried up, Senator Kerry's personal wealth provided his campaign new life (Edsall 2003).

${ }^{17}$ The 2008 money primaries could not be included in the 2004 model because of (1) the large number of candidates that opted out of the federal matching fund system, (2) the lack of data on money spent on fundraising by these candidates, and/or (3) the unreliability of data on money spent on fundraising by these candidates. Spending figures for money spent on campaign fundraising are required of candidates accepting federal matching funds in order to determine how much their campaign can spend. While a handful of individuals did not report any fundraising expenditures in the 1980-2004 period (i.e., George W. Bush, Steve Forbes, and John Connally), that defect could easily be minimized by a self-financing variable that accounted for these exceptional cases. In the 2008 contests, by contrast, the exception had become the rule since a majority of the serious contenders did not report those figures to the FEC.

${ }^{18} \mathrm{http}$ //www.fec.gov/finance/2008matching/2008matching.shtml (accessed February 1,2008$)$.

\section{REFERENCES}

Adkins, Randall E., and Andrew J. Dowdle. 2000. Break Out the Mint Juleps? Is New Hampshire the "Primary" Culprit in Predicting Presidential Nomination Outcomes. American Politics Quarterly 28:251-269. 
Adkins, Randall E., and Andrew J. Dowdle. 2001a. How Important Are Iowa and New Hampshire to Winning Post-Reform Presidential Nominations? Political Research Quarterly 54:431-444.

Adkins, Randall E., and Andrew J. Dowdle. 2001b. Is the Exhibition Season Becoming More Important to Forecasting Presidential Nominations? American Politics Research 29(3):283-288.

Adkins, Randall E., and Andrew J. Dowdle. 2002. The Money Primary Presidential Studies Quarterly 32:256-275.

Adkins, Randall E., and Andrew J. Dowdle. 2004. Bumps in the Road to the White House: How Did George W. Bush Win the Republican Presidential Nomination? Journal of Political Marketing 3:1-27.

Aldrich, John. 1980a. Before the Convention: Strategies and Choices in Presidential Nominations. Chicago: University of Chicago.

Aldrich, John. 1980b. A Dynamic Model of Presidential Nomination Campaigns. American Political Science Review 74:651-669.

Balz, Dan 1999. Bush's Fund-Raising Opens Huge Disparity; Unprecedented Edge Likely to Limit Rivals. Washington Post, July 1, p. A01.

Bartels, Larry M. 1988. Presidential Primaries and the Dynamics of Public Choice. Princeton, NJ: Princeton University.

Bartels, Larry M. 1985. Expectations and Preferences in Presidential Nominating Campaigns. American Political Science Review 79:804-815.

Brown, Clifford, Lynda Powell, and Clyde Wilcox. 1995. Serious Money: Fundraising and Contributing in Presidential Nomination Campaigns. Cambridge: Cambridge University Press.

Campaign Finance Institute. 2005. So the Voters May Choose: Reviving the Presidential Matching Fund System. Washington DC: Campaign Finance Institute.

Cohen, Marty; Karol, David; Noel, Hans; and Zaller, John. 2008. Political Parties in Rough Weather. The Forum 5(4), Article 3.

Damore, David. 1997. A Dynamic Model of Candidate Fundraising: The Case of Presidential Nomination Campaigns. Political Research Quarterly 50:343-364.

Dowdle, Andrew J., Randall E. Adkins, and Wayne P. Steger. 2008. The Viability Primary: Modeling Candidate Support Before the Primaries. Political Research Quarterly, forthcoming.

Edsall, Thomas B. 2003. Kerry Lends Campaign \$6.4 Million; House Mortgaged as Funds Dwindle. The Washington Post, December 24, p. A06.

Farrar, Donald, and Robert Glauber. 1967. Multicollinearity in Regression Analysis: The Problem Re-visited. Review of Economics and Statistics 49:92-107.

Goff, Michael J. 2004. The Money Primary: The New Politics of the Early Presidential Nomination Process. Lanham, MD: Rowman and Littlefield Press.

Grush, Joseph E. 1980. Impact of Candidate Expenditures, Regionality, and Prior Outcomes on the 1976 Democratic Presidential Primaries. Journal of Personality and Social Psychology 38(2):337-347.

Guerrant, Daniel G., and Paul-Henri Gurian. 1996. The Changing Impact of Viability During the Presidential Primary Season. Social Science Journal 33(2):137-148.

Gurian, Paul-Henri. 1996. Winnowing: The Strategy of Eliminating Opponents in Presidential Primaries. Paper presented at the Annual Meeting of the American Political Science Association, San Francisco, CA, August 28-September 1.

Gurian, Paul-Henri. 1993a. Candidate Behavior in Presidential Nomination Campaigns: A Dynamic Model. Journal of Politics 55(1):115-140. 
Gurian, Paul-Henri. 1993b. Primaries vs. Caucuses: Strategic Considerations of Presidential Candidates. Social Science Quarterly 74:310-321.

Gurian, Paul-Henri. 1990. The Influence of Nomination Rules on the Financial Allocations of Presidential Candidates. Western Political Quarterly 43:661-687.

Gurian, Paul-Henri. 1986. Resource Allocation Strategies in Presidential Nomination Campaigns. American Journal of Political Science 30:802-821.

Gurian, Paul-Henri, and Audrey A. Haynes. 1993. Campaign Strategy in Presidential Primaries, 1976-1988. American Journal of Political Science 37:335-341.

Haynes, Audrey A., Paul Henri-Gurian, and Stephen M. Nichols. 1997. The Role of Candidate Spending in Presidential Nominations. Journal of Politics 59:213-225.

Hinckley, Katherine, and John Green. 1996. Fund-raising in Presidential Nomination Campaigns: The Primary Lessons of 1988. Political Research Quarterly 49:693718.

Lewis-Beck, Michael. 1980. Applied Regression: An Introduction. Beverly Hills: Sage.

Magleby, David B., and William G. Mayer. 2008. Presidential Nomination Finance in the Post-BCRA Era. Pp. 141-168 in The Making of the Presidential Candidates 2008, ed. William G. Mayer. Lanham, MD: Rowman and Littlefield.

Malbin, Michael J. 2006. A Public Funding System in Jeopardy: Lessons from the Presidential Nomination Contest of 2004. Pp. 217-246 in The Election After Reform: Money, Politics, and the Bipartisan Campaign Reform Act, ed. Michael J. Malbin. Lanham, MD: Rowman and Littlefield.

Mayer, William G. 1996. Forecasting Nominations. Pp. 44-71 in In Pursuit of the White House: How We Choose Our Presidential Nominees, ed. William G. Mayer. Chatham, NJ: Chatham House.

Mayer, William G., and Andrew E. Busch. 2004. The Front-Loading Problem in Presidential Nominations. Washington, DC: Brookings.

Mutz, Diana. 1995. Effects of Horse-Race Coverage on Campaign Coffers. Journal of Politics 57(4):1015-1042.

Mosk, Matthew, and John Solomon. 2008. Clinton and Obama: Each Pull in Over $\$ 100$ Million. The Washington Post, January 1, p. A04

Newport, Frank. 1999. Republican Frontrunner One Year Before Presidential Election Almost Always Has Won Nomination. The Gallup Monthly, pp. 10-11.

Norrander, Barbara. 1993. Nomination Choices: Caucus and Primary Outcomes, 19761988. American Journal of Political Science 37(2):343-364.

Norrander, Barbara. 2000. The End Game in Post-Reform Presidential Nominations. Journal of Politics 62:999-1013.

Norrander, Barbara. 2006. The Attrition Game: Initial Resources, Initial Contests and the Exit of Candidates During the U.S. Presidential Primary Season. British Journal of Political Science 36:487-507.

Paolino, Phillip. 1994. Candidate Name Recognition and the Dynamics of the Presidential Nomination Process. Unpublished doctoral dissertation, Durham, NC: Duke University.

Reiter, Howard L. 1985. Selecting the Presidents: The Nomination Process in Transition. Philadelphia: University of Pennsylvania.

Seelye, Katharine, and Elisabeth Bumiller. 2008. With 3 States Set to Vote, A Dash About Chesapeake. New York Times, February 12, p. A17.

Stromer-Galley, Jennifer, and Andrea B. Baker. 2006. Blogs in Howard Dean's Primary Campaign. Pp. 111-131 in The Internet Election: Perspectives on the Web in Campaign 2004, eds. Andrew Paul Williams and John C. Tedesco. Lanham, MD: Rowman and Littlefield. 
Steger, Wayne P. 2000. Do Primary Voters Draw from a Stacked Deck? Presidential Nominations in an Era of Candidate-Centered Campaigns. Presidential Studies Quarterly 30:727-753.

Steger, Wayne P. 2008. Forecasting the Presidential Primary Vote: Multiple Candidates in Sequential Elections, International Journal of Forecasting, forthcoming.

Trippi, Joe. 2004. The Revolution Will Not Be Televised: Democracy, the Internet and the Overthrow of Everything. New York: Regan.

Vargas, Jose Antonio. 2008. Campaigns Experimenting Online to See What Works. The Washington Post, February 3, p. A14.

Will, George F. 2003. Dean Opting Out ... The Washington Post, November 13, p. A31. 
